\title{
CLASSROOM TECHNIQUES USED IN THE TEACHING OF ENGLISH BASED ON CURRICULUM 2013: A NATURALISTIC STUDY AT STATE JUNIOR HIGH SCHOOL OF SAWIT 1 BOYOLALI
}

\author{
Umi Nur Kurniliawati \\ State Junior High School of Sawit 1 Boyolali \\ Kateguhan, Sawit, Boyolali 57374 \\ umi.kurniliia@gmail.com \\ 085278951274
}

\begin{abstract}
This study is carried out to describe classroom technique used in the teaching of English at State of Junior High School of Sawit 1 Boyolali. The kinds of this research is describtive qualitative research especially naturalistic study in analyzing the data. The method of collecting data in this research are observation, interview and document. The finding of the study shows that there are some classroom techniques implemented by English teachers at SMP Negeri 1 State of Junior High School of Sawit 1 Boyolali, drilling, grouping, individual task, listening to music, picture describing, presentation, question and answer, questioning, reading aloud, repetition, role play, and translation. The teachers have roles as facilitator, teacher as motivator, teacher as observer, teacher as manager, teacher as model, teacher as counselor, teacher as controller, and teacher as evaluator. The students have roles as members of group, as tutor of other learners, as negotiator, as subject, and as monitor and evaluator of their own learning progress. There are some materials used by English teachers, such as: textbook, workbook, dictionary, photocopy exercises, powerpoint on LCD, audio like song, and videos from youtube. The conclusion of this research is that English teachers at State of Junior High School of Sawit 1 Boyolali used various classroom techniques which can improve the students' ability. Various techniques can make the students interested in English teaching-learning process. It does not make the class monotonous. The students become more active and creative. Based on the results, apparently, classroom techniques used by the teachers have important role in the teaching-learning process.
\end{abstract}

Keywords: Classroom techniques of teaching English, teachers'and students' roles, instructional material.

\begin{abstract}
ABSTRAK
Penelitian ini dibuat untuk mendeskripsikan classroom technique yang digunakan untuk pembelajaran bahasa Inggris berdasarkan kurikulum 2013 di SMP Negeri 1 Sawit Boyolali. Jenis penelitian ini adalah deskriptifkualitatif khususnya Natularistik Studi dalam menganalisis data. Metode yang digunakan dalam penelitian ini antara lain observasi, wawancara, dan dokumentasi.Temuan dalam penelitian ini menunjukkan bahwa teknik mengajar yang digunakan oleh guru bahasa Inggris di SMP Negeri 1 Sawit Boyolali antara lain drilling, grouping, individual task, listening to music, picture describing, presentation, question and answer, questioning, reading
\end{abstract}


aloud, repetition, role play, and translation.Peran guru dalam kelas antara lain sebagai fasilitator, sebagai observer, sebagai manager, sebagai model, sebagai konselor, sebagai kontroler, dan sebagai evaluator. Siswa mendapat peran sebagai anggota kelompok, pembelajar dari siswa lain, sebagai negosiator, sebagai subjek, dan sebagai monitor serta evaluator pada perkembangan belajar mereka sendiri. Ada beberapa materi yang digunakan oleh guru bahasa Inggris, seperti buku teks, lembar kerja siswa, kamus, latihan dalam bentuk fotocopy, power point pada LCD, musik dan lagu, dan video dari youtube. Kesimpulan dari penelitian ini yaitu para guru bahasa Inggris di SMP Negeri 1 Sawit Boyolali menggunkan banyak macam teknik mengjar dalam kelas yang dapat meningkatkan kemampuan belajar siswa. Berbagai macam teknik yang digunakan membuat siswa tertarik dengan proses belajar mengajar. Teknik-teknik yang digunakan tidak membuat siswa merasa bosan dengan proses pembelajaran. Hal itu menjadikan kelas tidak membosankan. Siswa menjasi lebih aktif dan kreatif. Berdasarkan hasil yang diperoleh, sesungguhnya teknik mengajar dalm kelas yang digunakan oleh guru memiliki peran yang amat penting dalam proses belar mengajar.

Kata Kunci: Teknik Mengajar dalam pelajaran Bahasa Inggris, Peran Guru dan Siswa, Materi Pendukung.

\section{INTRODUCTION}

In State of Junior High School of Sawit 1 Boyolali, English is one of many subjects thaught here. It is given to the seventh grade students. Curriculum that is used is Curriculum 2013 in the teaching-learning process. The teacher is responsible for the students to provide teaching techniques of learning English which are suitable for the students' need. Actually, teaching of English in State of Junior High School of Sawit 1 Boyolali is integrated teaching. It is not focused on each aspect of language skill. The teacher covers all of the four language skills in the general English. The teachers teach all aspects in one lesson. Within one meeting of the lesson, the teachers have to explain various aspects simultaneously. It is called integrated teaching.

State of Junior High School of Sawit 1 Boyolali obliges its students to learn the English subjects. In Englishclass, the teacher should play an active role in teaching all aspects of language skills. Themost of Junior High School studentsare teenager and include to the category of young learners. The young learners have many different characteristics. Their learning style and their capacity are different. Classroom techniques which are appropriate for students are needed here.

State of Junior High School of Sawit 1 Boyolali usually has problems since students often feel bored with English lessons in the classroom. The English class ofState of Junior High School of Sawit 1 Boyolali consist of 32students each class.It becomes important to make a research because as a researcher who wants to be a teacher, the writer have to know what are the best techniques used to teaching in English. Based on phenomenon above, the researcher tries to investigate the teachingand learning process especially the classroom techniquesused by the teacher teaches of English to achieve the learning objectives.

The researcher is interested in having a study in teaching-learning process especially the classroom technique on teaching of English class at State of Junior High School of Sawit 1 Boyolali. The writer wanted to deeply know the process of teaching-learning especially

Jurnal Penelitian Humaniora, Vol. 17, No. 1, Februari 2016: 23-30 
classroom techniques used by the teachers in teaching of English in State of Junior High School of Sawit 1 Boyolali.

The terms related to classroom technique is approach and metod. An approach is a theory of language and language Learning. It is called Axiomatic. Method is a procedure or overall plan of presentation usually used by the teacher to get their aims in the teaching learning process. It is a procedural of teaching-learning process. Technique is a classroom practice used by teacher or the implementation of approach and method.

As Anthony (in Fauziati 2002:16) views approach as "A set of correlative assumptions dealing with the nature of language and the nature of language teaching and learning. An aprroach is an axiomatic." Anthony (1963:95) also defines method as "an overall plan for the orderly presentation of language material, no part of which contradicts, and all of which is based upon the selected approach. An approach is axiomatic whereas a method is procedural", although technique is an implementation which actually takes place in a classroom. It is a particular trick, strategy, or contrivance used to accomplish an immediate objective. Technique must be consisten with a method, and therefore in harmony with an approach as well". (Anthony, 1963:36).

Classroom techniques play the important role. To reaches the goal of teaching-learning process, the teachers have to find and use the teaching techniques which are appropriate with the students' characteristics. Technique is something that actually takes place in language teaching or learning in the classroom.

Relevant to the above description on approach, method, and technique, Celce-Murcia (in Fauziati, 2014:15) give her summary stating that an approach is general (e.g. cognitive approach), that a method is specific set of procedures more or leess compatible with an approach (e.g. the silent way method), and that a technique is a very specific type of learning activity used in one or more methods (e.g. using colored rods of varying lengths to facilitate language practice in silent way).

Based on the review above, the writer is interested to describe types of techniques used in the teaching English at SMP Negeri 1 Sawit. To prove the originality of this research, the writer takes some previous study related to English teaching technique. There are Revellia (2014), Ahsan (2015), Prakusumasari (2015), and Ismayanindar (2015).

Revellia (2014) studied theTechniques of English Teaching used at SMP Muhammadiyah 5 Surakarta: A Naturalistic Study. The result of her research is that there are four techniques implemented by the teacher in teaching learning process of English of SMP Muhammadiyah 5 Surakarta. The techniques are namely Reading Aloud, Oral Repetition, Answering Question and Dialog Conversation. Ahsan (2015) found that the techniques in teaching reading to the seventh grade in SMP Negeri 2 Wonogiri are reading aloud and KWLH technique. Prakusumasari' study shows that the story mapping technique gives positive impact to the success of teaching reading of narrative text. It helps the students to comprehend the content of narrative text easily, story mapping technique helps them remembering the important content of reading narrative text, the students are able to analyze the generic structure of the text, and they are more interested in joining teaching-learning activities, the students have development of reading skill. Ismayanindar's (2015) study shows that teacher's corrective feedback techniques are appropriate and effective for the second year student of SMP N 1 Sragen in teaching descriptive text.

The current study focuses on classroom technique used in teaching of English which the subject in State of Junior High School of Sawit 1 Boyolali in 2015/2016 academic year includes the components of a technique itself, such as types of classroom techniques, the purposes in using each technique, teachers' and students' role in each types of classroom techniques. So, 
this study can extend the previous study and in other research field.

The writer applies several theories related with the previous study in order to support the data of research. There are several theories to support her research namely Notion of Approach, Method and Technique, Notion of Classroom Techniques of English Teaching, Classroom Techniques in teaching Listening, Classroom Techniques in teaching Speaking, Classroom Techniques in teaching Reading, Classroom Techniques in teaching Writing, and Instructional Material.

English teaching has four important skills namely listening skill, speaking skill, reading skill, and writing skill. Each skill has different technique to improve English teaching for the student.There are some techniques which can be used in the teaching listening, such as Bottomup processing, Top-down processing, Oral repetition, Identifying key words, Paraphrasing, Summarizing, Answering question, Brainstorming, Simultaneous listening and reading aloud. Classroom techniques used in teaching speaking are Discussion, Role play, Simulations, Information gap, Brainstorming, Story telling, Interviews, and Picture describing.

Activities to improve student's bottom-up skills in reading are recognizing word meanings, recognizing phrases, recognizing sentence structure and comprehension. Activities to improve student's top-down skills areadvance organizers, previewing, skimming and scanning, and prediction.Studies in the teaching writing have identified that there are at least three paradigms of teaching: the product approach, the process approach, and the genre-based approach.

Cunningsworth (in Brown 1994:7) stated that the role of materials (particularly coursebooks) in language teaching namely: (a) A resource for presentation materials (spoken and written), (b) A source of activities for learner practice and communicative interaction, (c) A reference source for learners on grammar, vocabulary, pronunciation, and so on, (d) A source of simulation and ideas for classroom activities, (e) A syllabus (where they reflect learning objectives which have already been determined), and (f) A support for less experienced teachers who have yet to gain in confidence.

Johnson and Paulston (in Brown 1994:7)said that learner role in individualized approach to language learning: (a) The learner is a planner of his or her own learning program and thus ultimately assumes responsibility for what he or she does in the classroom; (b) The learner is monitor and evaluator of his or her own progress; (c) Tearner is a member of a group and learns by interacting with others; (d) The learner is tutor of other learners; (e) The learner learns from the teacher, from other students, and from other teaching sources.

Richard (1985:23) states that there some teacher's role in the classroom such as: (1) Teacher as a facilitator, (2) Teacher as motivator, (3) Teacher as observer, (4) Teacher as manager, (5) Teacher as model, (6) Teacher as counselor, (7) Teacher as controller, and (8) Teacher as evaluator.

Based on the background above, the objectives of this study are to describe the followings: (1) the techniques used by the teacher in English teaching learning process, (2) the purposes of each technique, (3) the teacher' role, (4) the students' roles, and (5) the instructional materials.

\section{RESEARCH METHOD}

This research is a Naturalistic study about teaching of English at State of Junior High School of Sawit 1 Boyolali. Williams (1989:66) describes that "Naturalistic inquiry is inquiry conducted in natural settings (in the field of interests, not in laboratories), using natural methods (observation, interviewing, thinking, reading, writing) in natural ways by people who have natural interest in what they are studying (practitioners, such as teachers, counselors, and administrators as well as researchers and evaluators). This study gets the data from the 
observations made by the writer.

The writer gets the data from three sources, namely: events, informants, and documents. The method of collecting data in this research are observation, interview, and documentation. The techniques for analizing data in this research are reduction the data, display the data, drawing conclusion. The subject of this study is the English teachers and students of State of Junior High School of Sawit 1 Boyolali. The writer observs all of class in grade seven until nine. The teachers's name are Emi Titik Yami Yani, M.Pd., Dra. Siti Qomariah, and Nur Hariyani, S. Pd. The object of this research is the writer focus on the classroom techniques used in the teaching of English at State of Junior High School of Sawit 1 Boyolali in 2015/2016 academic year.

\section{FINDING AND DISCUSSION}

The research focuses on the questions of problem statement that are: 1) Types of classroom techniques in teaching English, 2) The purposes of using each technique, 3) Teachers' role, 4) Students' role, and 5) Instructional material used in the teaching of English at State of Junior High School of Sawit 1 Boyolali.

\section{Types of Classroom Techniques used in the Teaching Learning Process of English}

There are various kinds of teaching technique used by the teachers. Techniques used in class A in teaching English are Translation, Grouping, Checking, Listening to Music, Discussion, Presentation, Answering Question, Correcting, Reading Aloud, Drilling, Questioning, Repetition, and Picture Describing. The techniques used in class B are Correcting, Answering Question, Grouping, Presentation, Translation, Role Play, Question and Answer, Repetition, and Drilling. And the techniques used in class $\mathrm{C}$ such are Reading aloud, Repetition, Grouping, Drilling, Picture Describing, Checking, and Individual Task.

\section{The Purposes of Using Each Technique at SMP Negeri 1 Sawit Boyolali.}

With regards to the purpose of using the techniques, there are sixteen techniques used in the teaching learning process of English at State of Junior High School of Sawit 1 Boyolali. Each technique has its purpose are described below. The common teaching techniques used are as follows: (1) answering question is used to improve the students' understanding of the text and to help the teacher to know how far the students can understand the tex; (2) checking is used to correct students' word and to check their understand of the new vocabularies or the material that already explained by the teacher; (3) correction is used to correct students' word and to check their understand of the new vocabularies in this material; (4) correction is to correct students' word and to check their understand of the new vocabularies in this material; (5) discussions are to compare their work with their friends' work, make the students more active and creative, and share all information that the students know to their friends; (6) grouping is to share all of the material with their group; (7) individual task is to measure the students' ability in understanding the material and task given by the teacher; (8) listening to music is to improve the students' listening skill; (9) picture description is to improve the students' creativity; and (1) presentation is to see the students' ability in delivering their result of their discussion.

Other teaching techniques are less common. They are as follows: (1) question and answer is to know the students' ability to answer her question directly; (2) questioning is to train the student to have critical thinking; (3) reading aloud is to improve the students' reading skill; (4) repetition is to lead students to repeat the sentences or utterances with understanding the pronunciation, meanings and message; (5) role play is to make the students more fun in 
studying English, and (6) translation is to help the students to understanding the meaning of the words, phrases, or sentences that they have not understand before.

\section{Teachers' Role at State of Junior High School of Sawit 1 Boyolali.}

According to Richard (1985:23), teacher roles are related to the following issues: the types of functions teachers are expected to fulfill (e.g. practice director, counselor, facilitator, motivator, observer, manager, controller evaluator and model). There are many kinds of teachers' role in the teaching-learning process at SMP Negeri 1 SawitBoyolali namely: a. Teacher as Facilitator, b. Teacher as Motivator, c. Teacher as Observer, d. Teacher as Manager, e. Teacher as Model, f. Teacher as Counselor, g. Teacher as Controller, and h. Teacher as Evaluator. The writer conclude that teachers' role at State of Junior High School of Sawit 1 Boyolali are appropriate with Richard theory.

\section{Students' Role at State of Junior High School of Sawit 1 Boyolali.}

Johnson and Paulston (in Brown 1994:7)said that learner role in individualized approach to language learning: a) The learner is a planner of his or her own learning program and thus ultimately assumes responsibility for what he or she does in the classroom; b) The learner is monitor and evaluator of his or her own progress; c) Learner is a member of a group and learns by interacting with others; d) The learner is tutor of other learners; and e) The learner learns from the teacher, from other students, and from other teaching sources.

The students' role in the teaching of English at State of Junior High School of Sawit 1 Boyolali Boyolali are as follows:

a. The student as member of group: the purpose of using this technique is to sharing all of the material with their group. So, if they do not understand with the teachers' explanation, they can learn from their friends in their groups;

b. The student as tutor of other learners: tutor here means that the students facilitate by the teacher to learn with other students so the students can share their knowledge to another. The teacher is always dividing the students into a group or pairs. This technique has purpose to build the students' interaction;

c. Students as negotiator: there is interaction between the students and the teacher. It happened on English class when the teacher explaining some material and giving instruction, then at the time when the students feel confused with the assignment, they can ask until they understand it;

d. Student as subject: the teacher wants to build the students to explore their ideas in many cases. Some activities that can be used such as discussion and picture describing. In this occasion, the teacher gives opportunities to the students to explore their ideas and there is no limiting to them; and

e. Student as monitor and evaluator of his own learning progress: the students can monitor their learning progress from the result of their test. By seeing the result of the test, the students can see how far they understanding the material. If the students feel their result is bed, they can evaluate their learning program. They can change the learning style so that the result of their test will be better. The students have their own responsibility.

To sum up, the explanation above showed that the students' role at State of Junior High School of Sawit 1 Boyolali are appropriate with the Johnson and Paulston theory.

\section{Instructional Material used at State of Junior High School of Sawit 1 Boyolali.}

The materials are used by English teachers at State of Junior High School of Sawit 1 
Boyolali such as: textbook (Bahasa Inggris "When English Rings a Bell" written by Wachidah and Gunawan for seven grade, Bahasa Inggris "When English Rings a Bell" written by Wachidah and Gunawan for eight grade, Bahasa Inggris "When English Rings a Bell" written by Wachidah and Gunawan for nine grade), workbook (Bahasa Inggris written by Kurniawati and Arini), and dictionary. These materials are printed materials. Printed materials are materials that are printed such as textbook, workbook, dictionary, and photocopies exercises. Sometimes, the teacher also used the supplementary material taken from internet. It uses to enrich the materials on the textbook. The sources taken from internet are called non-printed sources.

Materials used at State of Junior High School of Sawit 1 Boyolali areappropriate with Richardtheory. According to Richard (1994) there are some forms of material:(1) printed materials such as books, workbooks, worksheets or readers, (2) non-print materials such as cassette or audio materials, video or computer-based materials, and (3) materials that comprise both print and non-print sources such as self-access materials and materials on the internet.

Based the description above, the writer concludes as follows: Syarif (2013) states that Curriculum 2013 is a form of integrated work betweenreconstruction of passing grade competence, suitability and adequacy, expansion, advancement of the materials, learning revolution and evaluation form.

Teaching of English in State of Junior High School of Sawit 1 Boyolali is integrated teaching. It is not focused in each aspect of skills. The teacher covers all of the skills in the general English. In State of Junior High School of Sawit 1 Boyolali,English lessons is done as a whole, has not focused on every skills such as listening, reading, writing, and speaking. The teacher teaches all aspects of it together in one lesson there. Within a meeting of the lesson, the teacher had to explain various aspects simultaneously. It is called integrated teaching.

It is appropriate with Syarif theory that in Curriculum 2013, teaching learning process using integrated teaching.

\section{CONCLUSION}

Based on the explanation above, the writer drawed the conclusion that English teachers at State of Junior High School of Sawit 1 Boyolali, Boyolali used various classroom techniques which can improve the students' ability. Various techniques can make the students interested with English teaching-learning process. It does not make the class monotonous. The students become more active and creative. Based on the results, apparently, classroom techniques used by the teachers have important role in the teaching-learning process.

\section{REFERENCES}

Ahsan, Annisa. 2015. Techniques in Teaching Reading to the Seventh Grade of SMP Negeri 2 Wonogiri. Research Paper. Surakarta: Universitas Muhammadiyah Surakarta.

Brown, H. Douglas. 1994. Teaching by Principles: An Interactive Approach to Language Pedagogy. USA: A Paramount Communications Company. Print

Fauziati. Endang. 2002. Teaching of English as Foreign or Second Language. Surakarta: Muhammadiyah University Press.

Ismayanindar. Nimas. 2015. The Teacher's Feedback Technique in Teaching Descriptive Text at the Second Year Of SMP N 1 Sragen. Research Paper. Surakarta: Universitas 
Muhammadiyah Surakarta.

Prakusumasari, Kukuh. 2015. The Use of Story-Mapping Technique in Teaching Reading Skill at the Second Year of SMP Muhammadiyah 6 Surakarta in 2014/2015 Academic Year. Research Paper. Surakarta: Universitas Muhammadiyah Surakarta.

Revellia, Shevita. 2014. Techniques of English Teaching used at SMP Muhammadiyah 5 Surakarta: A Naturalistic Study. Research Paper. Surakarta: Universitas Muhammadiyah Surakarta Richard, Jack. C. 1985. The Context of Language Teaching. New York: Cambridge University Press. Print.

Richard, Jack. C \& White. 2005. Teaching Writing: 154. Web. 26 October, 2015. http://richard. teachingwriting.edu.org.

Syarif. Hermawati. 2013. Teaching and Learning Models in Curriculum 2013. Web. 27 October, 2015. http://alumnivandeventer.org.

Sofina. 2014. Summary of Approaches and Methods: Web. 26 October, 2015. http://sofina-web. blogspot.co.id. 